\title{
Merger without Cost Advantages
}

\author{
STEFFEN HUCK \\ KAI A. KONRAD \\ WIELAND MUELLER
}

CESIFO WORKING PAPER NO. 1461

CATEGORY 9: INDUSTRIAL ORGANISATION

MAY 2005

An electronic version of the paper may be downloaded

- from the SSRN website:

www.SSRN.com

- from the CESifo website:

www.CESifo.de 


\title{
Merger Without Cost AdVAntages
}

\begin{abstract}
The seminal paper by Salant, Switzer and Reynolds (1983) showed that merger in a standard Cournot framework with linear demand and linear costs is not profitable unless a large majority of the firms are involved in the merger. However, many strategic aspects matter for firm competition such as the internal organization of the firm, the time structure of decision making, information aspects of competition, or the imbeddedness of firm competition in a strategic trade competition game between governments. This survey will reveal that the puzzle as in Salant, Switzer and Reynolds (1983) may be resolved without recurring to cost savings of merger. Firms interact with each other, with customers, suppliers, their owners, and with governments in many different ways, and inspection of these types of interaction reveals a multiplicity of reasons why merger can be profitable for the merging firms, even in Cournot markets with linear demand and cost.
\end{abstract}

JEL Code: D43, G34, L11, L13, L22, L41.

\author{
Steffen Huck \\ Department of Economics \& ELSE \\ University College London \\ Gower Street \\ London WC1E 6BT \\ United Kingdom \\ s.huck@ucl.ac.uk
}

\author{
Kai A. Konrad \\ WZB \\ Reichpietschufer 50 \\ 10785 Berlin \\ Germany \\ kkonrad@medea.wz-berlin.de
}

\author{
Wieland Mueller \\ Department of Economics \\ University of Tilburg \\ P.O. Box 90153 \\ 5000LE Tilburg \\ The Netherlands \\ w.mueller@uvt.nl
}




\section{Introducing a paradox}

The idea that a group of players, by way of joining forces and coordinating their actions, may gain in strength and improve their joint position vis-à-vis the other players is intuitively appealing. Applied to an oligopoly context, this idea suggests that the formation of a cartel, or a merger, among a subgroup of firms in a larger group of competing firms should benefit the members of this subgroup and harm the firms outside this group. The seminal paper by Salant, Switzer and Reynolds (1983) (henceforth SSR) showed that this intuition can go wrong, and indeed does go wrong: merger is unprofitable in a simple standard Cournot framework unless at least $80 \%$ of the firms in the industry are involved in the merger.

Intuitively, consider an industry that consists of three symmetric firms $\mathrm{A}, \mathrm{B}$ and $\mathrm{C}$ which compete in a Cournot oligopoly. Each of the firms receives $1 / 3$ of the industry. Now let two firms, $B$ and $C$, merge to one firm, $B \& C$. In this changed market situation the industry equilibrium is described by a Cournot duopoly. Each firm, $A$ and $B \& C$ set a quantity, and in the absence of cost advantages, these two firms are perfectly symmetric. Each receives $1 / 2$ of the duopoly profit. Firm $A$ 's profit is, hence, higher in the duopoly: it receives a larger share (half the industry profit, instead of one third of it) of a larger industry profit. The owners of the two firms $B$ and $C$ also receive $1 / 2$ of the industry profit and benefit from the increase in this profit. But their total share has become smaller. It is one half after the merger, but was two thirds prior to it. ${ }^{1}$

If firms $B$ and $C$ merge, they jointly prefer to offer a smaller quantity than the sum of their equilibrium quantities in the Cournot equilibrium with three firms, because they internalize a larger share of the negative externalities of increasing outputs. If the price falls, all firms are hurt not only the firm that triggered the price fall by increasing its output. Everything else unchanged, this contraction of output increases the joint profits of $B \& C$. However, firm $A$ anticipates that $B \& C$ will offer a smaller quantity, and, with Cournot competition, this makes $A$ increase its output. $B \& C$ suffers from this 'strategic' reaction of $A$, as the increased quantity reduces the equilibrium price also for the quantities that $B \& C$ sell. This effect overcompensates the benefit that $B \& C$ have from internalizing their own mutual competition effects in the SSR framework. The result resembles Harsanyi's (1977) bargaining paradox, in the sense that the cooperation of a subset of players harms this group. Conversely, outsiders gain.

\footnotetext{
${ }^{1}$ As is shown by Baye, Crocker and Ju (1996), the inverse profitability effect is obtained if a firm in a Cournot oligopoly divisionalizes in the sense of splitting up into a number of subdivisions who make their independent output choices.
} 
Empirical evidence suggests that outsiders often suffer when other firms merge (see, e.g., Banerjee and Eckard 1998), and bilateral mergers are observed in virtually all industries, even in industries where cost reductions are unlikely (see Office of Fair Trading 1999). Also, the stock market typically does not punish a merger, and typically does not reward the outsiders which are not involved in the merger (Bruner 2002). This may have many reasons and motivated a number of researchers to investigate the robustness of the merger paradox in a number of ways. The purpose of this paper is to survey the aspects that can make merger in a Cournot framework profitable.

Let us recall some of the explicit and implicit assumptions in SSR:

1. Firms have constant marginal cost, $c \geq 0$ with $c<a$, both before and after the merger. That is, a merger does not lead to cost reductions or synergies. ${ }^{2}$

2. Firms compete in quantities.

3. Firms face a linear (inverse) demand function (i.e., $P(x)=a-b X$ where $P$ is the market price and $X$ is industry output, which is the sum of all firms' outputs of a homogenous good in this industry.

4. Both before and after the merger, all firms are assumed to decide simultaneously about output.

5. When a merger of $m \leq n$ firms occurs, then the post-merger market is assumed to consist of $n-m+1$ firms. That is, there is a fusion of the $m$ merging firms in the 'atomic' sense such that $m-1$ firms simply disappear form the market.

6. Each firm is a single and homogenous centralized decision unit. For example, there is no distinction between ownership and management.

7. Firms have complete information about own and competitors' costs.

8. Firms are assumed to operate in an otherwise non-strategic environment.

9. Firms are only motivated by profit maximization.

Reviewing the existing literature, we describe what happens when all but the first of the above assumptions are relaxed. The puzzle as in SSR may be resolved and the seeming discrepancy

\footnotetext{
${ }^{2}$ Farrell and Shapiro (1990) refer to the case of no synergies when "the merged firm's production possibilities are no different from those of the insiders (jointly) before the merger." (p.112)
} 
between theory and empirical results can be reconciled recurring to cost savings or other merger synergies. ${ }^{3}$ However, this survey focusses on explanations other than such merger synergies.

\section{Resolving the paradox}

\subsection{Relaxing the assumption of quantity competition}

Deneckere and Davidson (1985) show that the results in SSR are sensitive to assumptions about the type of market interaction. They analyze a differentiated-goods oligopoly in which firms compete in prices and find that all mergers turn out to be profitable with this type of competition. Coming back to the intuition with three firms, $A, B$ and $C$ with three differentiated products $A, B$ and $C$. Coordinated activity between $B \& C$ will induce them to charge higher prizes for their products than otherwise, as they take into consideration that a higher prize of product $B$ will induce higher demand for product $C$, and this direct effect of price coordination benefits the firms. In turn, firm $A$ will anticipate this price increase. With Bertrand competition, firm $A$ will increase its price, too, and this will benefit $B \& C$, in addition to the direct benefit from coordination. ${ }^{4}$ Deneckere and Davidson also show that mergers are increasingly profitable in the sense that the more firms participate in the merger the higher the profits become.

The comparison of the analysis by SSR and Deneckere and Davidson reveals a general principle: The coordinated action of $B \& C$ makes them increase their profit, compared to independent choices of two firms $B$ and $C$, if the competitor $A$ sticks to its behavior in the oligopoly with 3 firms. But the anticipated change in the behavior of $B$ and $C$ will change the behavior of $A$. This additional 'strategic' effect, the change in the competitor's behavior, may, but need not harm the merging firms. It does harm the merging firms in some oligopoly games, such as in a Cournot framework with homogenous goods, but even benefits them in some other oligopoly frameworks. ${ }^{5}$

\footnotetext{
${ }^{3}$ The analyses by Perry and Porter (1985) and Farrell and Shapiro (1990) suggest that such synergies can resolve the puzzle as well. We are not questioning the empirical and theoretical importance of such synergies here. However, for competition policy it is important to highlight that synergies are not the only reason to make merger in Cournot markets profitable.

${ }^{4}$ More technically speaking, unlike with quantity competition in homogeneous-goods markets, reaction functions in price-setting differentiated-good markets are upward sloping. Therefore, the pre-merger situation is no longer an equilibrium as the merging firms have an incentive to raise their price in case outsiders keep their pre-merger prices. Because of the upward-sloping reaction functions, outsiders will also raise their price in response to the price increase of insiders. As a result, all prices in the new equilibrium after the merger are higher and all firms are better off.

${ }^{5}$ Posada and Straume (2004) shows that this can also be true in a spatial competition framework. Other con-
} 


\subsection{Relaxing the assumption of linear demand}

The assumption of linear demand is also important. Keeping the constant-marginal cost assumption and all other assumptions of SSR unchanged, Fauli-Oller (1997) and, more generally, Cheung (1992) show that the profitability of a merger depends on the degree of concavity of demand. To be more precise, let $P=P(X)$ be the inverse demand curve in the industry. Industry revenue is given by $P(X) X$ and marginal revenue is decreasing iff $2 P^{\prime}(X)+P^{\prime \prime}(X) X<0$. Define $\beta=\left(P^{\prime \prime}(X) X\right) / P^{\prime}(X)$ as the degree of concavity of demand. Note that if demands is linear (concave) [convex], then $\beta=0$ $(\beta<0)[\beta>0]$. Fauli-Oller $(1997)$ then shows that the greater the degree of concavity, the lower the profitability of a merger.

In particular, Cheung (1992) shows that for all demands satisfying $\beta>-2$ (which implies that the second-order condition of profit-maximization is satisfied), the minimal market share for a merger to be profitable is $50 \%$ which is clearly lower than the $80 \%$ threshold established by SSR for linear demand.

Recall that the profitability effect of merger mainly consists of a beneficial and a harmful effect: an increase in industry profit and a decrease in the share in these profits that goes to the merged firms. In the example with three firms, and the increase in industry profit tends to be smaller the more concave is demand.

Hennessy (2000) asks the question whether there is a 'well-behaved' demand function such that any set of firms can profitably merge. He identifies the demand function of the negativeexponential form given by $P(X)=A e^{-\lambda X}$ with $A>c$ and $\lambda>0$ and shows that with this demand function any number of firms can profitably merge if firms' marginal costs are sufficiently low.

\subsection{Relaxing the assumption of simultaneous decision making}

Several authors consider merger in markets in which not all firms make their decisions simultaneously and in which merger may change the timing of firms' decision making.

Daughety (1990) considers the specific case with two points of time for decision making: there are $m$ leaders and $n-m$ followers. The $m<n$ Stackelberg leaders first independently tributions relying on different aspects of spatial competition or spatial discrimination are Reitzes and Levy (1995), Norman and Pepall (2000), Rothschild (2000), Rothschild, Heywood and Monaco (2000), Heywood, Monaco and Rothschild (2001), Brito (2003), and Huck, Knoblauch and Müller (2003). Huck, Konrad and Müller (2002) consider the case of oligopoly markets with promotional competition and characterize conditions when a merger is profitable. Waehrer and Perry (2003) survey some of the literature on merger in auction markets and add to this literature. 
and simultaneously decide about their individual supply. Then, the remaining $n-m$ firms are Stackelberg followers who decide upon their quantity after learning about the total quantity supplied by the leaders. He shows that a merger of two followers $B$ and $C$ to the new entity $B \& C$, if it goes along with making this new entity belong to the group of Stackelberg leaders, may make the outcome more competitive: it may increase the industry output and welfare. Huck, Konrad and Müller (2001) analyze this framework further. In the subgame perfect equilibrium of this game each leader produces $(n-m+1)$ times the quantity of a follower with the result that each leader earns $(n-m+1)$ times as much as a follower. They consider three cases: (a) Merger of two leaders. In this case the number of leaders is reduced by one whereas the number of followers is left unchanged. (b) Merger of two followers who become one follower. In this case the number of leaders is left unchanged while the number of followers is reduced by one. (c) Merger of one leader and one follower, with the new firm staying a leader and continuing to use the old commitment technology of the former leader firm to commit itself on high output. Hence, in this case the number of leaders is left unchanged while the number of followers is reduced by one (as in case (b)).

In cases (a) and (b) two leaders (followers) have only an incentive to merge if there are only two leaders (followers) in the original market. These results show that, as in standard Cournot markets with linear costs, firms of equal power rarely have an incentive to merge. The picture changes when two firms of different commitment power merge. Merger between a leader and a follower as in (c) is always profitable. A follower's value if integrated in a leader firm (where it disappears) exceeds its value as a stand-alone firm. Or, to use the title metaphor of Huck, Konrad and Müller (2001), if a big fish eats a small fish, it is better off than both of them were as separate beings. Interestingly, this is true even though the big fish does not become 'bigger'. The newly merged firm produces the same quantity as the leader prior to merger. However, the price increases by so much that the profit loss due to the decrease in the joint quantity sold is overcompensated. This is not true for mergers between equally strong firms except in the cases identified above. As welfare is concerned, all discussed types (a)-(c) have the same effect. Total output is reduced and so is welfare, whereas the type of leadership generating merger as in Daughety (1990) turns out to be welfare enhancing.

As mergers between equally strong firms decrease joint payoffs in Cournot markets and, with some exceptions, also in Stackelberg markets, we expect merger rather to occur between firms with different strategic market power. In such cases antitrust authorities may be extremely wary as the firms' gain may not be due to efficiency gains as discussed by Farrell and Shapiro (1990). 
On the contrary, if the linear cost assumption seems justified, welfare is certainly to be reduced. Consequently, antitrust authorities may have every reason to be suspicious if two firms that have different strategic power plan to merge.

\subsection{Relaxing the assumption of a fusion in the 'atomic' sense}

SSR do not consider the possibly complex internal organization of a firm and assume that (a) a firm is run by a central decision unit and (b) that a firm $B \& C$ that results from a merger of firms $B$ and $C$ adopts the same decision structure as $B$ or $C$. In the following two subsections we discuss papers that relax these two assumptions.

\subsubsection{Multi-subsidiary organizational form or "staggered" competition}

Huck, Konrad, and Müller (2004) and, similarly, Creane and Davidson (2004), argue that a merger is not necessarily a process that transforms two firms into one firm of the same type, as assumed in SSR, basically eliminating one of the firms. A merger often leads to a different organization: merged firms $B$ and $C$ are kept as intact decision units within a more complex entity. Suppose the new entity, $B \& C$ consists of a joint headquarter (HQ) that can govern its affiliates, $B$ and $C$. In particular, suppose the $\mathrm{HQ}$ can enforce the sequence in which $B$ and $C$ decide about their output. The HQ may force affiliate $B$ to decide before $C$. If information flows freely between the two affiliates - which will be assumed here $C$ will be informed about the quantity of its sibling when making its own decision. The market will no longer be a simple Cournot market. Rather, if will have the flavor of a Stackelberg market as the affiliate that decides first becomes a "partial Stackelberg leader" (as opposed to the affiliate moving second that becomes a "partial Stackelberg follower"). This leadership is only partial as the outsiders will not be able to observe what the second-moving affiliate can observe. We refer to a merger that results in a holding where a HQ can enforce the timing of decisions of the two affiliates as "a merger with commitment by governance."

Analyzing this market we arrive at the following main conclusions: Bilateral mergers (a) are profitable if there are originally at least four firms in the market; (b) are always welfare-improving even if all firms have the same linear cost functions, and (c) always reduce the profit of firms not involved in the merger. ${ }^{6}$

\footnotetext{
${ }^{6}$ Particularly (b) relates to the result of leadership generating merger by Daughety (1990). Of course, here the change in leadership structure has an microeconomic underpinning, and the outcome of the merger is not a Stackelberg leader, but a more complex structure.
} 
Clever governance can induce a commitment advantage for the merged firm even if no other firm can observe what its affiliates are doing. A headquarter may provide this governance. Huck, Konrad and Müller (2004) show that the HQ is not needed, however. The timing of decisions inside $B \& C$ can emerge endogenously. With this type of self governance, the same beneficial Stackelberg commitment power can emerge endogenously. Thus, even if the merged firm does not benefit from "commitment by governance" it will increase its joint profit as it benefits from "endogenous commitment".

The policy implications are twofold: Socially, mergers may be more welcome than traditional views suggest. This, however, may depend on the organizational form merged companies choose. Hence, in judging the (anti)competitive effect of mergers, governing bodies may wish to be regardful of how the merged firm plans to operate. On a more general level, the analysis suggests that one can only fully understand the consequences of merger when carefully considering its consequences for market structure. If one does, the standard view that mergers have to induce cost advantages to be profitable and/or welfare-improving is not warranted.

\subsubsection{Owners hiring managers or the effect of strategic delegation}

Ziss (2001) as well as González-Maestre and López-Cuñat (2001) modify the framework by SSR and consider the incentive to merge if owners of firms hire managers to take final output decisions. Both papers compare merger profitability if managers' and owners' objectives coincide (the nondelegation regime as in SSR) and if owners delegate output decisions to managers and make a strategic choice of the objective functions.

In the delegation regime, it is assumed that each of the $n$ firms in the industry consist of an owner and a manager and that firms play a two-stage game: First, all owners simultaneously decide about the incentive scheme given to their managers. An incentive scheme may consist of a fixed payment plus a convex combination of firm profits and revenues. Specifically, owners decide about the parameter representing the weight attached to firm profits. Note that managers will be more aggressive if in their contracts positive weight is attached to the firm's revenue. Then, upon observing the contracts of all managers in the industry, all managers simultaneously decide about the final output of their firms. Under both regimes (delegation and non-delegation) it is assumed that after the exogenous merger of $m$ of the $n$ firms, $m-1$ firms "disappear" from the market such that the post-merger industry consists of $n-m+1$ firms. The main result of the two papers is that the minimum number of firms (or the market share) necessary for a merger to be profitable 


\begin{tabular}{lrrrrrrrrrrrrr}
\hline \hline$n$ & 3 & 4 & 5 & 6 & 7 & 8 & 9 & 10 & 15 & 30 & 100 & 140 & 1000 \\
\hline$m_{d}$ & 2 & 2 & 3 & 3 & 4 & 5 & 5 & 6 & 9 & 21 & 78 & 112 & 900 \\
$m_{d} \%$ & 66 & 50 & 60 & 50 & 57 & 62 & 55 & 60 & 60 & 70 & 78 & 80 & 90 \\
$m_{n d}$ & 3 & 4 & 4 & 5 & 6 & 7 & 8 & 9 & 13 & 26 & 92 & 130 & 970 \\
$m_{n d} \%$ & 100 & 100 & 80 & 83 & 86 & 88 & 89 & 90 & 87 & 87 & 92 & 93 & 97 \\
\hline \hline
\end{tabular}

Note: $n$ is the number of firms; $m_{d}$ (respectively $m_{n d}$ ) is the minimal number of merger participants for a merger to be profitable in the delegation model (respectively the non-delegation model) and $m_{d} \%$ (respectively $m_{n d} \%$ ) stands for its percentage relative to $n$.

Table 1: Profitability of exogenous mergers in the delgation model versus the non-delegation model of Salant et al. (1983)

can not be greater under a delegation regime than under a non-delegation regime. The result is illustrated in Table 1 that is adapted from González-Maestre and López-Cuñat (2001).

Consider for example the case of $n=4$, that is the case in which the pre-merger industry consists of four firms. Whereas under the non-delegation setup of SSR all firms have to be part of the merger in order to make it profitable, only two firms (or 50\%) are necessary under the delegation regime. Furthermore, recall SSR's $80 \%$ minimum requirement for a merger to be profitable. Under delegation this requirement only applies when there are more than 140 initial firms (and demand is linear). For more general demand curves, Ziss (2001) shows that the minimum market share required for mergers (under delegation regimes) to be profitable is non-decreasing in the degree of concavity, $\beta$, under a delegation regime (for the definition of $\beta$ see sections 2.2 ). ${ }^{7}$ Finally, when firms merge in markets in which delegation is used both before and after the merger, welfare is reduced as they involve a reduction in output.

Why are fewer firms necessary under delegation than under non-delegation to make merger profitable? González-Maestre and J. López-Cuñat (2001) point out that with delegation each firm can act aggressively along two dimensions: manager compensation and quantity. It is true that the reduction of the number of firms after the merger lessens competition among firms under both regimes. The reduced extent of competition, however, is amplified under delegation as the reduction of firms lessens competition not only with regard to quantities (as in the non-delegation regime) but also on managers' compensation schemes.

\footnotetext{
${ }^{7}$ Thus, this result shows that the finding in Fauli-Oller (1997) reported in section 2.2 is also true in markets with delegation.
} 


\subsection{Relaxing the assumption of complete information}

SSR assume that both before and after the merger all firms have complete information about rivals' costs. This assumption is relaxed in Amir, Diamantoudie, and Xue (2004). Specifically, these authors start with a pre-merger industry as in SSR where all firms have the same and publicly known constant marginal costs equal to $c$. However, after a bilateral merger outsiders are uncertain about the merged entity's new costs. More precisely, with probability $p$ outsiders believe that the merged firm has marginal costs $c_{l}<c$ after the merger. ${ }^{8}$ With the complementary probability $1-p$ outsiders believe that the merged firm's costs stays at $c$. This means that whereas the merged entity knows the exact value of its marginal costs after the merger, all outsiders only know the probabilities with which the two possible levels of the merged firm's marginal costs will occur.

In the post-merger Bayesian equilibrium, outsiders continue to choose a unique output whereas the merged entity chooses a quantity depending on whether own costs are low or the same as before the merger. In order to assess the effects of the incomplete information regarding possible cost savings two approaches are possible. The first is to compute expected outputs and profits at the Bayesian equilibrium. However, as Amir et al. (2004) we focus on a worst case scenario that assumes that the merged firm fails to achieve any post-merger cost reductions. It turns out that if outsiders believe with sufficiently high probability that the merged firm will experience sufficiently high costs reductions, then the merger is profitable even if ex post no cost savings materialize. This result is established by deriving two threshold values: one regarding the belief and one regarding the efficiency gain. In a number of plausible examples Amir et al. (2004) show that the two thresholds are such that the scope for profitable bilateral mergers is quite broad. To illustrate this refer to Figure 1 that is adapted from Amir et al. (2004). This Figure shows for several initial numbers of firms, $n$, the region of $\left(p, c_{l}\right)$ space for which a bilateral merger is profitable in case demand is given by $p(X)=10-X$ and pre-merger marginal costs are $c=3$. In each case, the merger is profitable below the given curve and unprofitable above it.

Amir et al. (2004) offer some arguments for why with incomplete information a bilateral merger can be profitable. For this purpose, first recall that in the original SSR setup the merged firm reduces its output post merger (in order to internalize the business-stealing externality on its merging partner) while outsiders respond to this by expanding output. Amir et al. (2004, p.12) then write: "By contrast, in the present Bayesian setting, the merged firm exploits its informational

\footnotetext{
${ }^{8}$ This setup contains the case of no cost savings at all such that (as becomes clear below) we are not strictly departing from our basic assumption that a merger does not lead to a cost reduction for the mergerd firm.
} 


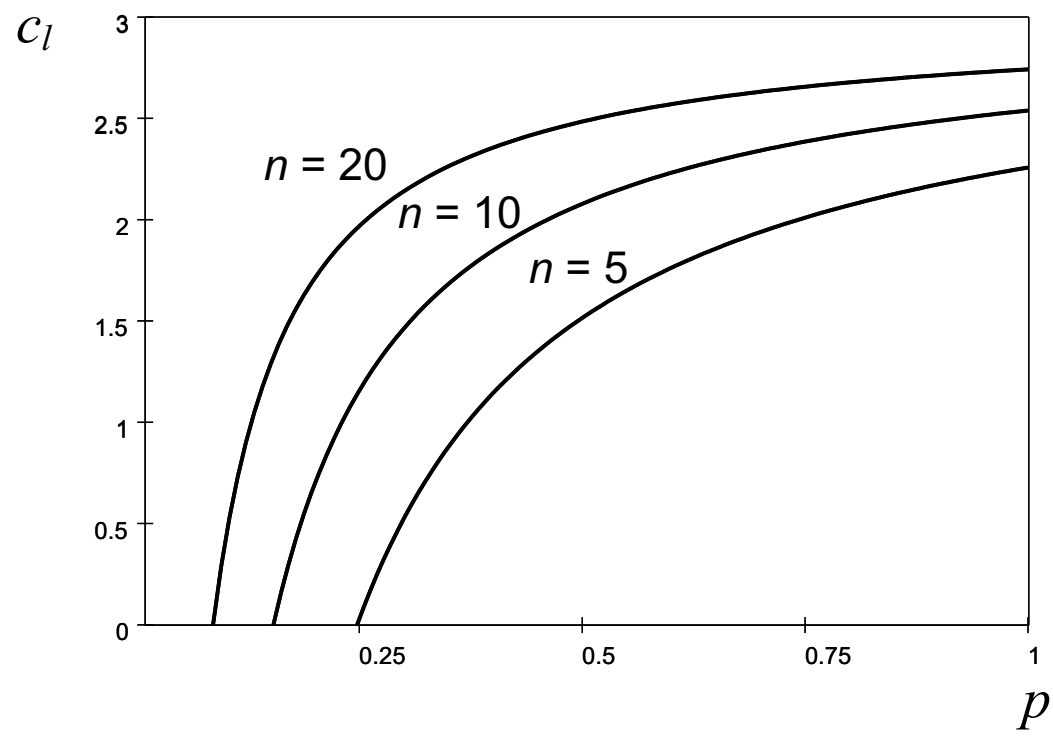

Figure 1: The region of $\left(p, c_{l}\right)$ space for which a bilateral merger is profitable.

market power that lies in the ability of the outsiders to adapt their outputs to its true unit costs. Depending on the belief held by outsiders, this new market power may well lead to the merged firm producing more than before the merger, despite the fact that the aforementioned externality effect is still present here. While a tendency for the outsiders' output to move in the opposite direction is still there, there is a range of values $p[\ldots]$ for which all firms decrease their output after the merger, even in the worst case scenario."

The result by Amir et al. (2004) implies that firms have an incentive to misrepresent the cost savings achieved by a merger both with regard to antitrust authorities (in order to get the merger cleared) and with regard to competitors (in order to influence their beliefs). It is interesting to recall Fisher's (1987, p.36) statement: "The burden of proof as to cost savings or other offsetting efficiencies, however, should rest squarely on the proponents of a merger, and here I would require a very high standard. Such claims are easily made and, I think, often too easily believed." With regard to the model analyzed in Amir et al. (2004), antitrust authorities should be reluctant to accept cost-reduction arguments, since at least in the worst case scenario industry price is unambiguously higher (and, thus, welfare lower) after the merger. 


\subsection{Relaxing the assumption of a non-strategic environment}

In SSR, the only agents other than the homogenous decision makers in firms are the customers who behave non-strategically as price takers. However, firms often interact in an environment with other strategic players, for instance, governments, unions, or other upstream firms that supply inputs.

One important example is if the labor market is unionized. If firms interact with unions, merger may change the bargaining power of the union(s) and the firm(s), depending on how the labor market is organized. With global, nationwide wage bargaining, an international merger can shift bargaining power from the unions to the firm, as the firm may be able to shift production from one country to another as a response to labor union demands, and this may make merger more profitable. Lommerud, Straume and Sørgard (2005) consider this and related questions in an international oligopoly. One conclusion is that cross-border merger is a likely outcome if the merger decision is endogenized.

A further example emerges in the context of strategic trade policy. If the different firms in an industry are located in different countries but compete in the same market, the government of the country in which a particular firm is located may choose export duties or subsidies to change the market outcome in this international competition in a way that is favorable from the country's perspective. As in Brander and Spencer (1985), if a country government subsidizes the export of a firm that is located in this country, from the firm's perspective, this is like a reduction in the firm's per-unit cost of production of the units exported. Such a firm will choose higher output than without subsidies. This is anticipated by competitor firms. In turn, in a Cournot framework, trade subsidies in one country will induce competing firms to choose smaller quantities in the equilibrium. The subsidized firm gains from the reduction in its competitors' outputs. If more than one firm are located in a country, subsidization policy is less effective. A subsidy paid to, say, firm $B$ in a country will also reduce exports of competitors in the same country. Hence, subsidies to several firms in one country mutually harm the respective other firm and changes a county government's incentives to use strategic trade subsidies. Dixit (1984) analyses how the strategic trade policy that is chosen by the governments, and the welfare effects, depend on the number and location of firms between the different countries. A country government chooses higher strategic trade subsidies if the number of firms located in this country is smaller.

Trade policy and the industry concentration through competition policy are closely interdependent in such a framework, and this has been studied in a number of studies. ${ }^{9}$ Huck and Konrad

\footnotetext{
${ }^{9}$ Cowan (1989) studies competition policy and trade policy with one importing and one exporting country. The
} 
(2004) analyze the effect of a change of the industry structure through different types of merger in this context for the profitability of firms. National and international merger differ considerably in their implications for profitability. If two firms inside one country merge, the government of this country will increase strategic trade subsidies, and other countries will reduce the subsidies they offer to firms located in their country. National merger is therefore more profitable for the merging firms than in the SSR framework. Non-merging firms in the same country also benefit, but outsider firms in other countries may lose. International merger has very different implications. ${ }^{10}$

\subsection{Relaxing the assumption of mere profit maximization}

Huck et al. (2004) provide experimental evidence for a psychological force that might render mergers as in SSR (weakly) successful: Simon's aspiration levels. ${ }^{11}$ More precisely, Huck et al. (2004) implement markets with originally three or four firms, respectively. Demand in these markets is linear and all firms have the same constant unit costs. The performance in these markets is observed for 25 initial periods. Then a bilateral merger is implemented such that four-firm markets become three-firm markets and three-firm markets are turned into duopolies. Post-merger markets are then observed for another 25 periods. Huck et al. (2004) find that theory predicts total outputs well but largely fails to predict individual outputs. In particular, merged firms are significantly more aggressive than their competitors and as a result mergers are (weakly) profitable in case of initially four firms.

Given the institutional details of their design, Huck et al. (2004) offer three plausible explanations for what is observed: (a) the mere fact that one firm has resulted from a merger renders the firm "strong" and the whole market asymmetric; (b) as the merged firms are jointly owned (and profits are to be shared), fairness considerations may induce subjects to shift output from unmerged to merged firms; (c) merged firms are committed to maintaining their original interdependence of competition policy and strategic trade policy has also been analysed by Richardson (1999) and Head and Ries (1997). Horn and Levinsohn (2001) emphasizes the role of sequencing of these two policy measures. Rysman (2001) also considers a framework in which countries first choose the number of firms (via competition policy) and then use strategic trade policy.

${ }^{10}$ Huck and Konrad (2004) use their results to explaining why Airbus Industries may have disliked the merger between its strongest competitors in the US, Boeing and McDonnell-Douglas. Strategic trade policy tends to play a big role in this market, and the merger of Boeing and McDonnell-Douglas should induce the US government to increase their subsidies and the EU government to reduce their subsidies. In turn, the merger may be profitable, but unprofitable for Airbus Industries.

${ }^{11}$ See Simon $(1955,1959)$. 
profits because of aspiration levels created in the pre merger markets.

With the help of two control treatments, explanations (a) and (b) could be excluded. Thus, it seems that the success of mergers in the markets with originally four firms is driven by aspiration levels. Firm owners do not want to see their profits fall such that merger history seems to matter mainly because firms form aspiration levels prior to the merger.

\section{Concluding remarks}

The analysis by SSR showed an important benchmark result: merger tends to reduce the merging firms' share in industry profit, and, even though industry profit increases, the merger is typically not profitable for the merging firms in the linear benchmark framework. Mergers should be expected to take place only if it is in the interest of those deciding about the merger. This basic insight caused a research programme that looks for reasons for why merger can be profitable. Alleged synergies or cost savings clearly are one reason that may make merger more profitable. However, such synergies are difficult to observe or measure, and, moreover, it turns out that there are several other reasons for why firms might wish to merge. We collect and survey some of the more important reasons that have been identified in recent years. This survey shows that many strategic interactions other than the one considered in the quantity setting Cournot game are profit relevant, like the role of the internal organization of the firm, or strategic interaction with other players such as governments or input suppliers, can render merger profitable in the absence of synergies or production efficiency effects. Taking these factors into consideration is important for competition policy, as, unlike cost savings or synergies, these profitability increasing factors are less straightforward to evaluate from a welfare point of view.

\section{References}

[1] Amir, R., E. Diamantoudie, and L. Xue (2004): Merger performance under uncertain efficiency gains, Working Paper, McGill University.

[2] Banerjee, A. and E.W. Eckard (1998): Are mega-mergers anticompetitive? Evidence from the first great merger wave, RAND Journal of Economics, 29, 803-827.

[3] Baye, M.R., K.J. Crocker and J. Ju (1996): Divisionalization, franchising and divestiture incentives in oligopoly, American Economic Review, 86, 223-236. 
[4] Brander, J. and B. Spencer (1985): Export subsidies and international market share rivalry, Journal of International Economics, 18, 83-91.

[5] Brito, D. (2003): Preemptive mergers under spatial competition, International Journal of Industrial Organization, 21(10), 1601-1622.

[6] Bruner, R.F. (2002): Does M\&A pay? A survey of evidence for the decision-maker, Journal of Applied Finance, 12 (1), 48-68.

[7] Cheung, F.K. (1992): Two remarks on the equilibrium analysis of horizontal merger, Economics Letters 40, 119-123.

[8] Cowan, S. (1989): Trade and competition policies for oligopolies, Weltwirtschaftliches Archiv, $125,464-483$.

[9] Creane, A. and C. Davidson (2004): Multidivisional firms, internal competition, and the merger paradox, Canadian Journal of Economics 37, 951-977.

[10] Daughety, A.F. (1990): Beneficial concentration, American Economic Review 80, 1231-37.

[11] Deneckere, R., and C. Davidson (1985): Incentives to form coalitions with Bertrand competition, RAND Journal of Economics 16(4), 473-486.

[12] Dixit, A. (1984): International trade policy for oligopolistic industries, Economic Journal, 94, $1-16$.

[13] Farrell, J., and C. Shapiro (1990): Horizontal mergers: An equilibrium analysis, American Economic Review 80, 107-126.

[14] Faulí-Oller, R. (1997): On merger profitability in a Cournot setting, Economics Letters 54, 75-79.

[15] Fisher, F.M. (1987): Horizontal mergers: Triage and testament, Journal of Economic Perspectives, Autumn, 23-40.

[16] González-Maestre, M. and J. López-Cuñat (2001): Delegation and mergers in oligopoly, International Journal of Industrial Organization 19, 1263-1279.

[17] Harsanyi, J. (1977): Rational behavior and bargaining equilibrium in games and social situations, Cambridge, Cambridge University Press. 
[18] Head, K., and J. Ries (1997): International mergers and welfare under decentralized competition policy, Canadian Journal of Economics, 30, 1104-1123.

[19] Hennessy, D.A. (2000): Cournot oligopoly conditions under which any horizontal merger is profitable, Review of Industrial Organization 17, 277-284.

[20] Heywood, J.S., K. Monaco and R. Rothschild (2001): Spatial price discrimination and merger: The N-firm case, Southern Economic Journal, 67(3), 672-684.

[21] Horn, H. and J. Levinsohn (2001): Merger policies and trade liberalization, Economic Journal, 111, 244-276.

[22] Huck S., V. Knoblauch, and W. Müller (2003): On the profitability of collusion in location games, Journal of Urban Economics, 54(3), 499-510.

[23] Huck, S. and K.A. Konrad (2004): Merger profitability and trade policy, Scandinavian Journal of Economics, 106(1), 1-16.

[24] Huck, S., K.A. Konrad, and W. Müller (2001): Big fish eat small fish: On merger in Stackelberg markets, Economics Letters 73, 213-217.

[25] Huck, S., K.A. Konrad and W. Müller (2002): Merger and collusion in contests, Journal of Institutional and Theoretical Economics, 158(4), 563-575.

[26] Huck, S., K.A. Konrad, and W. Müller (2004): Profitable horizontal mergers without cost advantages: The role of internal organization, information, and market structure, Economica $71,575-587$.

[27] Huck, S., K.A. Konrad, W. Müller, and H.-T. Normann (2004): The Merger Paradox and Why Aspiration Levels Let It Fail in the Laboratory, Working Paper, University College London.

[28] Lommerud, K.E., O.R. Straume and L. Sørgard (2005): Downstream merger with upstream market power, European Economic Review, 49(3), 717-743.

[29] Norman, G. and L. Pepall (2000): Profitable mergers in a Cournot model of spatial competition, Southern Economic Journal, 66(3), 667-681.

[30] Office of Fair Trading (1999): Merger appraisal in oligopolistic markets, Economic Research Paper no. 19, November. 
[31] Perry, M.K., and R.H. Porter (1985): Oligopoly and the incentive for horizontal merger, American Economic Review 75, 219-227.

[32] Posada, P. and O.R. Straume (2004): Merger, partial collusion and relocation, Journal of Economics, 83(3), 243-265.

[33] Rothschild, R. (2000): Merger under spatial competition, Urban Studies, 37(3), 443-449.

[34] Rothschild, R., J.S. Heywood and K. Monaco (2000): Spatial price discrimination and the merger paradox, Regional Science and Urban Economics, 30(5), 491-506.

[35] Reizes, J.D. and D.T. Levy (1995): Price-discrimination and mergers, Canadian Journal of Economics, 28, 427-436.

[36] Richardson, M. (1999): Trade and competition policies: concordia discors?, Oxford Economic Papers, 51, 649-664.

[37] Rysman, M. (2001): Competition policy as strategic trade, mimeo., Boston University.

[38] Salant, S.W., S. Switzer, and R.J. Reynolds (1983): Losses from horizontal mergers: the effects of an exogenous change in industry structure on Cournot-Nash equilibrium, Quarterly Journal of Economics 98, 185-99.

[39] Simon, H.A. (1955): A behavioral model of rational choice, Quarterly Journal of Economics 69, 99-118.

[40] Simon, H.A. (1959): Theories of decision making in economics and behavioral science, American Economic Review 49, 253-283.

[41] Stennek, J. (2003): Horizontal Mergers Without Synergies May Increase Consumer Welfare, Topics in Economic Analysis 83 Policy 3, Article 1.

[42] Waehrer, Keith, and Martin K. Perry, 2003, The effects of mergers in open-auction markets, RAND Journal of Economics, 34(2), 287-304.

[43] Ziss, S. (2001): Horizontal mergers and delegation, International Journal of Industrial Organization 19, 471-492. 


\title{
CESifo Working Paper Series
}

\author{
(for full list see www.cesifo.de)
}

1397 Marko Köthenbürger, Panu Poutvaara and Paola Profeta, Why are More Redistributive Social Security Systems Smaller? A Median Voter Approach, February 2005

1398 Gabrielle Demange, Free Choice of Unfunded Systems: A First Assessment, February 2005

1399 Carlos Fonseca Marinheiro, Sustainability of Portuguese Fiscal Policy in Historical Perspective, February 2005

1400 Roel M. W. J. Beetsma and Koen Vermeylen, The Effect of Monetary Unification on Public Debt and its Real Return, February 2005

1401 Frank Asche, Petter Osmundsen and Maria Sandsmark, Is It All Oil?, February 2005

1402 Giacomo Corneo, Media Capture in a Democracy: The Role of Wealth Concentration, February 2005

1403 A. Lans Bovenberg and Thijs Knaap, Ageing, Funded Pensions and the Dutch Economy, February 2005

1404 Thiess Büttner, The Incentive Effect of Fiscal Equalization Transfers on Tax Policy, February 2005

1405 Luisa Fuster, Ayşe İmrohoroğlu and Selahattin İmrohoroğlu, Personal Security Accounts and Mandatory Annuitization in a Dynastic Framework, February 2005

1406 Peter Claeys, Policy Mix and Debt Sustainability: Evidence from Fiscal Policy Rules, February 2005

1407 James M. Malcomson, Supplier Discretion over Provision: Theory and an Application to Medical Care, February 2005

1408 Thorvaldur Gylfason, Interview with Assar Lindbeck, February 2005

1409 Christian Gollier, Some Aspects of the Economics of Catastrophe Risk Insurance, February 2005

1410 Gebhard Kirchgässner, The Weak Rationality Principle in Economics, February 2005

1411 Carlos José Fonseca Marinheiro, Has the Stability and Growth Pact Stabilised? Evidence from a Panel of 12 European Countries and Some Implications for the Reform of the Pact, February 2005

1412 Petter Osmundsen, Frank Asche, Bård Misund and Klaus Mohn, Valuation of International Oil Companies -The RoACE Era, February 2005 
1413 Gil S. Epstein and Shmuel Nitzan, Lobbying and Compromise, February 2005

1414 Marcel F. M. Canoy, Jan C. van Ours and Frederick van der Ploeg, The Economics of Books, February 2005

1415 Eric A. Hanushek and Ludger Wößmann, Does Educational Tracking Affect Performance and Inequality? Differences-in-Differences Evidence across Countries, February 2005

1416 George Kapetanios and M. Hashem Pesaran, Alternative Approaches to Estimation and Inference in Large Multifactor Panels: Small Sample Results with an Application to Modelling of Asset Returns, February 2005

1417 Samuel Mühlemann, Jürg Schweri, Rainer Winkelmann and Stefan C. Wolter, A Structural Model of Demand for Apprentices. February 2005

1418 Giorgio Brunello and Lorenzo Rocco, Educational Standards in Private and Public Schools, February 2005

1419 Alex Bryson, Lorenzo Cappellari and Claudio Lucifora, Why so Unhappy? The Effects of Unionisation on Job Satisfaction, March 2005

1420 Annalisa Luporini, Relative Performance Evaluation in a Multi-Plant Firm, March 2005

1421 Giorgio Bellettini and Carlotta Berti Ceroni, When the Union Hurts the Workers: A Positive Analysis of Immigration Policy, March 2005

1422 Pieter Gautier, Michael Svarer and Coen Teulings, Marriage and the City, March 2005

1423 Ingrid Ott and Stephen J. Turnovsky, Excludable and Non-Excludable Public Inputs: Consequences for Economic Growth, March 2005

1424 Frederick van der Ploeg, Back to Keynes?, March 2005

1425 Stephane Dees, Filippo di Mauro, M. Hashem Pesaran and L. Vanessa Smith, Exploring the International Linkages of the Euro Area: a Global VAR Analysis, March 2005

1426 Hans Pitlik, Friedrich Schneider and Harald Strotmann, Legislative Malapportionment and the Politicization of Germany's Intergovernmental Transfer System, March 2005

1427 Konstantinos Angelopoulos and Apostolis Philippopoulos, The Role of Government in Anti-Social Redistributive Activities, March 2005

1428 Ansgar Belke and Daniel Gros, Asymmetries in the Trans-Atlantic Monetary Policy Relationship: Does the ECB follow the Fed?, March 2005

1429 Sören Blomquist and Luca Micheletto, Optimal Redistributive Taxation when Government's and Agents' Preferences Differ, March 2005 
1430 Olof Åslund and Peter Fredriksson, Ethnic Enclaves and Welfare Cultures - QuasiExperimental Evidence, March 2005

1431 Paul De Grauwe, Roberto Dieci and Marianna Grimaldi, Fundamental and NonFundamental Equilibria in the Foreign Exchange Market. A Behavioural Finance Framework, March 2005

1432 Peter Egger, Stefan Gruber, Mario Larch and Michael Pfaffermayr, Knowledge-Capital Meets New Economic Geography, March 2005

1433 George Economides and Apostolis Philippopoulos, Should Green Governments Give Priority to Environmental Policies over Growth-Enhancing Policies?, March 2005

1434 George W. Evans and Seppo Honkapohja, An Interview with Thomas J. Sargent, March 2005

1435 Helge Berger and Volker Nitsch, Zooming Out: The Trade Effect of the Euro in Historical Perspective, March 2005

1436 Marc-Andreas Muendler, Rational Information Choice in Financial Market Equilibrium, March 2005

1437 Martin Kolmar and Volker Meier, Intra-Generational Externalities and InterGenerational Transfers, March 2005

1438 M. Hashem Pesaran and Takashi Yamagata, Testing Slope Homogeneity in Large Panels, March 2005

1439 Gjermund Nese and Odd Rune Straume, Industry Concentration and Strategic Trade Policy in Successive Oligopoly, April 2005

1440 Tomer Blumkin and Efraim Sadka, A Case for Taxing Education, April 2005

1441 John Whalley, Globalization and Values, April 2005

1442 Denise L. Mauzerall, Babar Sultan, Namsoug Kim and David F. Bradford, Charging $\mathrm{NO}_{x}$ Emitters for Health Damages: An Exploratory Analysis, April 2005

1443 Britta Hamburg, Mathias Hoffmann and Joachim Keller, Consumption, Wealth and Business Cycles in Germany, April 2005

1444 Kohei Daido and Hideshi Itoh, The Pygmalion Effect: An Agency Model with Reference Dependent Preferences, April 2005

1445 John Whalley, Rationality, Irrationality and Economic Cognition, April 2005

1446 Henning Bohn, The Sustainability of Fiscal Policy in the United States, April 2005

1447 Torben M. Andersen, Is there a Role for an Active Fiscal Stabilization Policy? April 2005 
1448 Hans Gersbach and Hans Haller, Bargaining Power and Equilibrium Consumption, April 2005

1449 Jerome L. Stein, The Transition Economies: A NATREX Evaluation of Research, April 2005

1450 Raymond Riezman, John Whalley and Shunming Zhang, Metrics Capturing the Degree to which Individual Economies are Globalized, April 2005

1451 Romain Ranciere, Aaron Tornell and Frank Westermann, Systemic Crises and Growth, April 2005

1452 Plutarchos Sakellaris and Focco W. Vijselaar, Capital Quality Improvement and the Sources of Growth in the Euro Area, April 2005

1453 Kevin Milligan and Michael Smart, Regional Grants as Pork Barrel Politics, April 2005

1454 Panu Poutvaara and Andreas Wagener, To Draft or not to Draft? Efficiency, Generational Incidence, and Political Economy of Military Conscription, April 2005

1455 Maurice Kugler and Hillel Rapoport, Skilled Emigration, Business Networks and Foreign Direct Investment, April 2005

1456 Yin-Wong Cheung and Eiji Fujii, Cross-Country Relative Price Volatility: Effects of Market Structure, April 2005

1457 Margarita Katsimi and Thomas Moutos, Inequality and Relative Reliance on Tariffs: Theory and Evidence, April 2005

1458 Monika Bütler, Olivia Huguenin and Federica Teppa, Why Forcing People to Save for Retirement may Backfire, April 2005

1459 Jos Jansen, The Effects of Disclosure Regulation of an Innovative Firm, April 2005

1460 Helge Bennmarker, Kenneth Carling and Bertil Holmlund, Do Benefit Hikes Damage Job Finding? Evidence from Swedish Unemployment Insurance Reforms, May 2005

1461 Steffen Huck, Kai A. Konrad and Wieland Müller, Merger without Cost Advantages, May 2005 